Original Research Paper

\title{
Human Capital Competitiveness in ASEAN Economic Community (AEC): The Role of Regulation, Indonesia Experiences
}

\author{
${ }^{1}$ Salmiaty Taty, ${ }^{2}$ Bayu Taufiq Possumah and ${ }^{3}$ Ridwan Ismail Razak \\ ${ }^{1}$ Sekolah Tinggi Ilmu Ekonomi (STIE) YPUP Makassar, Indonesia \\ ${ }^{2}$ School of Social and Economic Development, Universiti Malaysia Terengganu, Malaysia \\ ${ }^{3}$ Educational Development of South Sulawesi, Indonesia
}

Article history

Received: 27-09-2016

Revised: 03-11-2016

Accepted: 08-02-2017

Corresponding Author: Bayu Taufiq Possumah School of Social and Economic Development, Universiti Malaysia Terengganu, Malaysia Email: bayu@umt.edu.my

\begin{abstract}
The AEC is an economic integration between ASEAN countries with the creation of a free market generally in the context of capital, goods and services and labor. The AEC opens the gate for all countries to invest and have better mutual cooperation. Indonesia experienced a big leap from 50 to 37 in the World Economic Forum (WEF) competitiveness ranking. As the largest population in the ASEAN, Indonesia must work harder to compete with the advanced educated labor force from Singapore, Malaysia and Thailand. Some challenges to develop the human capital. The problems that exist in the context of human resources and labor in Indonesia today such as lack of expertise, low education, inadequate facilities, low competitiveness, unemployment, imbalance salaries, low productivity and many others, but these problems do not make Indonesia retreat and avoiding the free market competition. MEA 2015 should not lead Indonesian labor plunged in their own home, but MEA expected to drive Indonesian workers able to exchange experiences and advance skill from other countries.
\end{abstract}

Keywords: Human Capital, Regulation, Competitiveness, ASEAN Economic Community

\section{Introduction}

Indonesia is currently racing in the vortex of the Southeast Asia free market, or commonly known as the ASEAN Economic Community (AEC), which had begun in 2015. The AEC is an economic integration between ASEAN countries with the creation of a free market generally in the context of capital, goods and services and labor for sure. The impacts are the flow of goods and services, investment and skilled labor freely to the rest of the ASEAN countries without significant barriers. It means that if associated with goods then there is no duty or tax, easy work permits for foreign workers, so that the MEA opens the gate for all countries to invest and have better mutual cooperation.

In the World Economic Forum (WEF) ranking, the competitiveness of Indonesia experienced a big leap from 50 to 38. This was a huge achievement for Indonesia and only surpassed by Ecuador and Lesotho. However, Indonesia's ranking still under the ratings of other ASEAN countries, especially Singapore, Malaysia,
Thailand and Brunei Darussalam. This triggers a big question whether Indonesia is ready for the ASEAN Economic Community (AEC)?

AEC was formed with a mission to generate better economy atmosphere in ASEAN and be able to compete with countries whose economies are more advanced. In addition, by the realization of the AEC, ASEAN would be able to create more strategic position in the international arena. In the implementation of AEC in 2015, as the largest country in Southeast Asia Indonesia certainly faces some challenges, both external and internal. External challenges such the level of trade competition is increasingly fierce, the growing trade deficit with other ASEAN countries and how Indonesia enhance its investment attractiveness. Meanwhile, internal challenges include the lack of public understanding of AEC, unpreparedness regions to face the AEC, the level of regional development are not balanced and the condition of employment and human resources.

Currently the Human Development Index (HDI) Indonesia was ranked 121 st out of 187 countries. It was 
way far below neighbouring countries such as Singapore (ranked 18th), Malaysia (ranked 64th), Thailand (ranked 103rd) and the Philippines (ranked 114th). In this ASEAN Economic Community (AEC) era, competition in the labour market becomes more extensive and the demand for high quality of human resources is primed and ready to compete. Based on the report of the World Economic Forum (WEF, 2016), Indonesia's competitiveness in ranked 37 and still lower compared to some neighbouring countries such as Singapore (ranked 2nd), Malaysia (ranked 18th) and Thailand (ranked 32nd), while refer to the global talent competitiveness index 2015-16 Indonesia in ranked 90 for low middle income countries. In fact, the structure of the Indonesian workforce pointed at a total of 55.3 million $(46.8 \%)$ only graduated from elementary school. If these conditions are not immediately corrected, the potential of this nation will only be used by other countries. Indonesia will become a market for surplus production of other countries and will lead to Indonesia's trade balance becoming worse.

One of the human resources potential which until now has not been touched is the mental aspect of work culture. In the private sector, generally has created a good work culture. Thus the mental revolution will be concerned on the government's bureaucracy. The ultimate goal is creating a bureaucracy to support national competitiveness.

\section{Research Methodology}

In order to achieve the objective of study, we do a research library that would be poured in some subtopics. Critical discussions regarding strengths and weaknesses of human capital development will be discussed in next section. This part important proposed, so that we all could see clear equivalent discussion about the role of government regulation and supervision. By qualitative descriptive method this paper attempts to explore how Indonesian government regulate human capital in Indonesia to face challenges and opportunities of in progress ASEAN Economic Community (AEC).

\section{Human Capital Development in Indonesia}

One of the most important ideas to discuss labor in economics is how to set marketable skills of workers as a form of capital in which workers make a variety of investments. This perspective is important in understanding both investment incentives and the structure of wages and earnings in international competitive era. This is why, one of the most strategic issue under discussion recently about the implementation of the ASEAN Economic Community (AEC) is an attempt to establish free trade among ASEAN countries especially on labor market. In terms of competitiveness, level of education Indonesian labor among ASEAN countries such Singapore, Malaysia and Thailand is measured by comparing the ratio of diploma/university level over total workforce. The table below shows that during the range years the ratio of highly educated workforce in Indonesia at 7.02. While other countries such Thailand and Malaysia have average ratio 13.38 and $23 \%$ respectively.

This data explains clearly that qualification of Indonesian workers in term of higher education (Diploma/University) is still the lowest compared to other ASEAN countries especially Singapore, Malaysia and Thailand. Core Institute Indonesia says that about $67 \%$ of 240 million of Indonesian workforce graduated only from 9th school grade while $80 \%$ Singaporean unemployment dominated by college graduates. This analysis can be a detrimental factor for Indonesia if the AEC free market totally operated. Barriers of Indonesian workers in the era of internationalization is kind of language and differences in labor regulations. The need to improve the language skills and understanding of the rules in the ASEAN countries is very urgent.

The discourse of human resources development, especially at the regional level regards to the issue of quantity, components, deployment and quality. Where these issues are interrelated and affected the planning, implementation, development and success of development (Harbison and Miyers, 1964)

Indonesian large amount population can be a good starting point if it has adequate quality. This refers to the concept that human is an actor, executor and audience of development itself. Hence, with the low quality of the population, then they would be more as a connoisseur and lesser role as actors and development practitioners. Therefore, Human Resources Development in Indonesia basically includes two major problems. In this case in addition to the need for development of human potential such like intellectual and intelligence that is developed through the principles of technocratic and character with moral implications. So the underline of these two issues is that human resource development related to improving the quality of human being, as a subject of labor and technological development implications subject to the human existence itself. Human Resources Development in the era of globalization should be preferred, because in the periods the applied super-advanced technology has penetrated into all aspects of human life. If we did not anticipate the negative implication, then human will be shifted by machines. The numbers of workers likely do not get the opportunities; competition is tighter because of employment opportunity provided more filled by machines/robot which significantly more practical and efficient than human labor.

Massive changes in this technological era, human resource development faced a complicated problems and 
dilemma. On one side, we are trying to industrialize by applying a variety of sophisticated technology, but it had been known that the real consequences of the application of machinery and a variety of other technologies would further reduce the chance of human labor (particularly unskilled labor). Meanwhile, on the other hand we are faced with problem of population (large population) that has not been utilized effectively, so that the existence of this population is at a critical point as the burden of development. Indonesia's population problem at the moment is how to create human capital become more qualified (skilled and educated).

\section{Human Capital in Indonesia: The Challenges}

Several labor conditions are serious problems and require an effective government role to overcome in order to achieve high competitiveness human resources to face the global competition especially the Asian Economic Community (AEC). Some of the problems that need to be focus on such as.

\section{The Low Quality of Workforce}

One essential factors for effectively implementation of services and FDI liberalization as well as for deeper economic integration in the AEC is skilled labour mobility. Foreign skilled is needed to augment the domestic pool, as well as to create the competitive synergy for domestic labour. However this an opportunity and at once a challenges for Indonesia.

The quality of the workforce in a country can be determined by looking at the level of the country's education system Workers in Indonesia mostly at the level of lower education. This led to the lower mastery of science and technology. The lack of mastery of science and technology leads to the low productivity, so this will effect on the lower quality of goods and services production. (Rahman, 2015).

\section{Disproportional Number of Labour Force with Job Opportunities}

The increasing number of labour force which is not offset by the expansion of employment will bring a burden for the economy. Labour force who cannot be accommodated in the labour market will cause unemployment. Though the government wishes the increasing number of labour force could drive the economic development. Macro-economic growth is strong enough for more than a decade and gradually been able to reduce unemployment in Indonesia. However, with about two million Indonesian population each year plunge into the labour market, it is a very big challenge for the Indonesian government to stimulate the creation of new employment opportunity so that the labour market could absorb job seekers which each year continues to grow. Youth unemployment (most are those who just graduated from college) is one of the main concerns and need their quick action. With a total population of approximately 250 million people, Indonesia is the fourth most populous country in the world (after China, India and the United States). Furthermore, this country also has a quite big young population because approximately half of Indonesia's population aged less than 30 years. If the two factors mentioned above are combined, indicates that Indonesia is a country with a large labour force, which will develop into an even greater future.

\section{Uneven Labour Distribution}

Most workers in Indonesia are located in Java Island. While in other areas are still a shortage of labour, especially for agriculture, plantation and forestry. Thus in Java, unemployment keeps counting, while in other areas there are many natural resources have not been managed optimally.

\section{Unemployment}

An economic crisis in Indonesia resulted in many industries have gone bankrupt. Then many workers lost their job, the narrowness of existing employment but the labor force continues to grow. Based on the data released by the Central Statistics Agency (BPS) in the Official Bulletin of Statistics No. 38/05/Th. XVII, May 5,2014 , the state employment per month of February 2014 is as follows:

- $\quad$ The labour force in February 2014 reached 125.3 million people; increased by 5.2 million people compared to the labour force in August 2013 as many as 120.2 million or an increase of about 1.7 million people compared with February 2013

- The number of people working in February 2014 reached 118.2 million people; increased by 5.4 million people compared to the amount in August 2013 as many as 112.8 million or an increase of 1.7 million compared to the total labour in February 2013

- Unemployment Rate in February 2014 reached $5.70 \%$; and the rate decreased compare to the rate in August 2013 amounted to $6.17 \%$ while in February 2013 amounted to $5.82 \%$

- During the last year (February 2013-February 2014), total of workforce has increased in almost all sectors, especially in social services sector as many as 640 thousand people $(3.59 \%)$, trade sector as many as 450 thousand people $(1.77 \%)$ and 390 thousand people $(2.60 \%)$ in manufacturing sector. While agricultural sector was to declining $0.68 \%$ of the workforce

- Based on the number of hours worked in February 2014, as many as 81.2 million people $(68.71 \%)$ 
worked over $35 \mathrm{~h}$ per week, while the workforce with the number of hours worked less than $15 \mathrm{~h}$ per week reached 7.3 million people $(6.16 \%)$

In February 2014, the workforce with elementary education level still dominate as many as 55.3 million people $(46.80 \%)$, while the workforce with education of Diploma pointed at 3.1 million people $(2.65 \%)$ and at the level of university graduation only as many as 8.8 million people $(7.49 \%)$. From those BPS data can be concluded that the labor force participation rate increased and unemployment decreased. However, with the declining of unemployment rate did not mean that Indonesia has made significant progress and declared ready to fight in the MEA free market. Indonesia still has a wide range of domestic problems that is why the Indonesian government has not been so focused to face on MEA matter but rather occupy something endlessly, such as issues of politics. Moreover, the government seems does not concern about job creation that have high impact in global markets and prevent overwhelm labor from other countries as well as discrimination against gender workers, inadequate salaries/wages, labor protection issues and others.

\section{Human Resource Development Strategy}

Adam Smith in his The Wealth of Nations very early discusses the concept of the development of labour and its importance for economic development of the country. In economic perspective, human as one of production factors is capital which used to create goods or services (Dae Bong, 2009). In this regard of strategy, there are some things that should be the top priorities in the human resources quality development among other things. The first thing is how to build good education system and qualified. To achieve this kind of state, it is necessary restructure the education system as a whole, especially on to the quality itself, as well as its relevance to the needs of society and the jobs requirement. Government has an important role to delivery an effective and efficient education system, oriented to the mastery of science and technology and evenly distributed throughout the country. The second is to strengthen the role of religion in social life in order to strengthen the nation's identity and personality (character building). The third is capacity building through training, competency and others. Professional and skilled manpower according to the demands of the market is a factor of nation superiority to face the global competition. Government plays an important role in preparing strategic programs to produce qualified human resources and ready to enter the job market. Last but not least, is developing the society especially the younger generation. As a main pillar in the wheel of development, the empowerment of young generation is expected to create a creative, innovative and highly competitive generation. Youth characteristics such like is expected to contribute and win the global competition.

Kamar Dagang Indonesia (KADIN) or Indonesian business and Industry association, stated that they have prepared three programs in order to face the AEC 2015 also supports the MP3EI:

- Identify the professional/skilled needs to support 22 economic activities in six economic corridors and increase the competitiveness of 12 priority sectors AEC 2015

- Facilitate the development of competency standards and the establishment of professional certification (LSP) by the relevant Industry Association in 22 economic activities and 12 priority sectors AEC 2015

- Development of KADIN Training Centre (KTC) to encourage the development of competency-based training program as required by the Provincial Kadin industry

Kadin also inventory 12 priority sectors AEC 2015 called free flow of skilled labor, such as follow: Health care, tourism, logistics services, e-ASEAN, air travel transport, agro-based products, electronic goods, fisheries, rubber-based products, textiles and apparels, automotive and wood-based products (Orbeta and Kathrina, 2013).

Other strategic step to prepare skilled manpower and professional to face the AEC is Indonesia also have to standardize the professional quality of the workforce. This is due to the quality and quantities of labor in other countries are much better. Indonesia will be in the audience seats and watch if standardization is not obtained considering the companies require workers who have excellent qualities and skills to keep the business alive. That is the foundation why standardization is required when competes in the labor force. Strategic policies that can be taken and implemented through employment programs are as follows:

Development and expansion on working opportunity program:

- Reinforce the employment policy

- Associate working opportunity program

- Elevate services for the labours to go overseas

- Establish cooperation on integrated information system development with the international labour market

Labour productivity and quality improvement program in such ways:

- Function enhancement and revitalization of working training institution to become a training institution based on competency

- Intensively organized internship training program nationally as well as globally 
- Facilitate education institutions and on job training

- Re-arrange and develop national standard of working competition

Protection program and development of labour union in the way of:

- Increasing the quantity and quality of industrial relation supervisor

- Increasing the supervision, protection and law enforcement but not to forget the occupational health and safety

- Development of social security workers

Effective Labor market policy plays a central role in supporting job creation, through ensuring that businesses can access people with the right skills to help them to start up and grow. Effective Policies can build employability and promote mobility conducive to higher productivity and efficient matches between skills and opportunities. At the same time, the search for efficiency in the delivery of national policies and programmes can lead to a lack of attention to the negative effects that a "one size fits all" approach can have in certain regions (OECD, 2014).

\section{Indonesian Government Human Capital Policy in Facing AEC Free Market}

Several things need to be underlined if Indonesia really jumps deeper into this AEC free market, as follow:

\section{Raising Human Capital Quality}

Refer to secretary general OECD report, today Indonesia is out-performing most of its regional neighbors and most other emerging market economies, but by accelerating reforms it can do even better, grow even faster and ensure that all Indonesians share the benefits of growth. Improving the education system and the country's infrastructure will be critical to future success. The Policy Review points out that Indonesia faces a unique window of opportunity: with $43 \%$ of its 250 million-strong population under the age of 25 , the country is already endowed with the human resources necessary to propel growth, provided its workforce is equipped with the right skills. To reap the demographic dividend, the Indonesian government must raise the quality of education, through improvements in teacher training, professional development and increased accountability. It must extend participation in the education system, to ensure that all students have an equal chance to progress to higher levels of learning and it must strive for greater efficiency within the education sector.

The Economic Survey points out that the central government's strong fiscal position-marked by low deficits and low public debt-offers the opportunity to raise greater revenues to fund higher spending targeted at improving education, boosting infrastructure and expanding the social security system. Better targeting of existing social security programs would ensure that measures to alleviate poverty, including cash transfers, health care spending and food subsidies, benefit those most in need. Reducing high levels of labor market informality, through the easing of labor market rigidities, would improve incentives for workers to join the social security system.

\section{Employment Legalization}

Although rules about labor in Indonesia spread in the various legislations, for instance the Act No. 13 of 2003 says Manpower is the basic rule that contains management thoroughly and comprehensively in the context of employment. This is as the rules of employment in Indonesia when entering the AEC free market. However, is the Act able to protect the workers especially when going into the AEC? With so many companies and foreign workers who will enter later on, will this Act also protect Indonesian workers? For example, in every speech or demonstration conducted by the workers, the implementation of contract system and outsourcing based on the Act seems to weaken the bargaining position of workers because there is no job security, certainty of wages, even the certainty of welfare benefits thus that workers/labors requested to be removed. But sometimes the government often accused deleting or change particular rules that protect the workers interest for the sake of investment come in to Indonesia. With the cancellation of several Clauses such as Clause 120 subsection (1) and (2), Clause 155 subsection (2) and Clause 158, the existence of Law Number 13 Year 2003 about Employment that result this Act is not intact anymore so the Law is indeed feasible to immediately refine again. But this refine matter is not as easy as turning the palm, a lot of sliced interest between employee and employment was hard to get the win-win solution.

Based on the Radbruch (1950) theory, a law can be said to be good if they meet three conditions, namely philosophically establish justice, sociologically helpful and legally able to create certainty. In short, Radbruch's formula can be express concisely as:

\section{"Appropriately enacted and socially effective, norms lose their legal character or their legal validity when they are extremely unjust." (That is: Extreme injustice is no law).}

The regulations of employment are made to achieved peace and fulfill those three requirements. The government presence should give protection to workers especially Indonesian and does not take sides only for 
the interests of capital owners. To deal with the MEA, the Law on Employment is expected to be enhance to meet the three conditions because Indonesian workers is one of the components that significantly affect the economic, political and social aspects.

\section{Law Enforcement of Labor Inspectors}

Labor inspection should be carried out in accordance with the provisions of Article 134 Number 13 Year 2003 which states that "In order to realize the implementation of the rights and obligations between workers and employers, the government must carry out supervision and enforcement of labor legislation". In the face of the MEA, the position of inspectors becomes very important in order to be more conducive industrial relations and as protection for workers in this global competition. Preparation Efforts must be addressed to the quality as well as quantity of labor inspectors to supervise the implementation of the Act No. 13 of 2003 about employment.

In terms of quality, with the change of government system which initially centralistic system to decentralized governance authorities was much more rely on the county/city. However, the department of labor which should protect the workers could be said still unable to function properly since many of the labor inspector educational background and work experience does not support.

In terms of quantity, based on the data obtained from the Ministry of Manpower and Transmigration, the number of inspectors in 2013 recorded about approximately 2,400 people in Indonesia and they must oversee about 216,000 companies in Indonesia. The distribution of labor inspector until now is only reaching roughly 300 districts from more than 500 districts. This way far than ideal given the disparity is too far between the amounts of law enforcement with the total companies that must be monitored.

\section{Labor Market Policies in Sending and Receiving Countries}

In this sense Indonesia must create awareness and understand their labor markets, particularly the types of skills that are needed and the potential barriers for obtaining those skills. Indonesia also must put the right policies and institutions in place and for that they must identify the labor problems and learn from the best practices. The awareness covering such as:

\section{Working Hour}

The labor market tradition of treating the contract between employees and employers as a private matter should be prevented by the Indonesia government from intervening on matters of working hours and rest days for live-in domestic workers because they still not covered by the Employment Act. This particular act for example should has provisions on one rest day per week, maximum working hours per week, mandated paid sick leave and limits to salary deductions which covers both local and foreign workers except for FDWs. A simple solution would have been extending the coverage of the Employment Act and Workmen's Compensation Act to FDWs and that only exemptions could be left to the negotiations between employer and FDWs (Chia, 2011). The ILO has identified five key principles to optimize the arrangement of working hours, including promoting "healthy" working hours so that workers have adequate rest periods, ensuring "family friendly" hours, promote gender equality through working hours, optimizing productivity through working hours, as well as workers involved in the regulation of working hours. Arrangements more effective working hours believes will be able to improve social and economic results of the company, thus increasing the viability and "win-win" solutions for both workers and employers.

\section{Wages}

Increasing productivity of human resources is very important for the economy as a whole as it can maintain its competitiveness globally. In a reason the majority of human resources in Indonesia who have long working hours with relatively low wages, the increase in productivity becomes an important element towards the economy more competitive and prosperous. HR productivity was defined as GDP per worker, has increased gradually over time in Indonesia, where the level of productivity in the industrial sector almost doubled to the productivity of the service sector and four times compare to the agricultural sector.

Therefore, the function of large-scale enterprises is important to the Indonesian economy and the needs to pay more attention to strengthen micro, Small and Medium Enterprises (SMEs) through the interventions of the labor market (Tran, 2015). In particular, investment in apprenticeship may be highly relevant to overcome the phenomenon of "missing middle part" while boosting the productivity.

\section{Conclusion}

The problems that exist in the context of human resources and labor in Indonesia today such as lack of expertise, low education, inadequate facilities, low competitiveness, unemployment, imbalance salaries, low productivity and many others, but these problems do not make Indonesia retreat and avoiding the free market competition. AEC 2015 should not lead Indonesian labor plunged in their own home, but AEC expected to drive Indonesian workers able to exchange experiences and advance skill from other countries. With most of productive age population, it is very difficult to hold Indonesian workers working and competing in the AEC 2015. However, the quality of Indonesian workers who 
are majority still in the informal labor will be a problem to face the AEC because there will be limitation on informal workers.

With the AEC, awareness of the importance of quality in social life becomes an importance part of encouraging competitiveness and value of competition in each of man powers. AEC should be able to be best utilized as a media of self-promotion in the regional arena and as training momentum for Indonesian workers to compete internationally with more qualified than other countries. With the AEC Indonesia should be able to see a good opportunity to improve the quality of human resources to improve competitiveness, provide adequate education and health and also provide information in term of the importance of the AEC itself.

Improvement in the field of education and training system will help Indonesia in equipping the workforce with the required technical skills to meet the demands of the labor market in the present and future. This action should include responsive provision of technical and vocational training system, encourage cooperation between training centers with employers to develop the curriculum and apprenticeship system, engage in publicprivate dialogue to anticipate the need for skills in the future, as well as improving accessibility and relevance of tertiary institutions.

\section{Funding Information}

We would like to inform that the funding for construction this paper is from author's own.

\section{Author's Contributions}

Salmiaty Taty: Designed the research plan, organized the study, create discussion and contributed to the writing of the article.

Bayu Taufiq Possumah: Develop the methodology used in this study, correcting references, article review and the literature

Ridwan Ismail Razak: Contributed the idea, discussion and writing the article

\section{Ethics}

Authors should address any ethical issues that may arise after the publication of this manuscript.

\section{References}

BPS, 2014. Official Bulletin of Statistics. Central Statistics Agency.

Chia, S.Y., 2011. Free Flow of Skilled Labor in the AEC. In: Toward a Competitive ASEAN Single Market: Sectoral Analysis, Urata, S. and M. Okabe (Eds.), ERIA Research Project Report, pp: 205-279.
Dae Bong, K., 2009. Human capital and its measurement. Proceedings of the 3rd OECD World Forum on Statistics, Knowledge and Policy Charting Progress, Oct. 27-30, Building Visions, Improving Life Busan, Korea.

Harbison, F.H. and C.A. Myers, 1964. Education, Manpower and Economic Growth: Strategies of Human Resource Development. 1st Edn., McGrawHill, New York, pp: 229.

OECD, 2014. Effective local strategies to boost quality job creation, employment and participation. Report prepared for the G20 Labour and Employment Ministerial Meeting Melbourne, Australia.

Orbeta, J.A. and G. Kathrina, 2013. Managing international labour migration in ASEAN: Themes form a six-country study. Institutions, Actors and Processes, Geneva, Switzerland.

Radbruch, G., 1950. Legal Philosophy. In: The Legal Philosophies of Lask, Radbruch and Dabin, Lask, E., G. Radbruch and J. Dabin (Edn.), Harvard University Press, Cambridge, ISBN-10: 0674493001, pp: 536-536.

Rahman, A.S., 2015. Daya saing tenaga kerja indonesia dalam menghadapi Masyarakat Ekonomi Asean (MEA). Ilmu Hubungan Int., 3: 117-130.

Tran, T.T.H., 2015. Challenges of Small and MediumSized Enterprises (SMEs) in vietnam during the process of integration into the ASEAN Economic Community (AEC). Int. J. Account. Finan. Report., 5: 133-143. DOI: 10.5296/ijafr.v5i2.8298

WEF, 2016. The Global Competitiveness report 20162017. The Global Competitiveness and Risks Team, World Economic Forum. 